\title{
„Společná havárie“ a její stř̌edověký právní život v Baltském moři
}

\author{
Vojtěch Vrba
}

Fakulta právnická, Západočeská univerzita

Kontaktni e-mail:vovrba@volny.cz

\section{General Average and Its Life in Baltic Sea in Middle Ages}

\begin{abstract}
:
The paper discusses development and fundamental elements of general average principle. While its origins are nowadays agreed upon being set thoroughly in ancient era of Roman law, there surely is a significant development of accesoric relations that were incorporated in the principle itself during middle ages. The work tries to point them out, through presentation of general average adopted in hanseatic cities between $9^{\text {th }}$ and $16^{\text {th }}$ centuries. Also, briefly are presented the principal legal sources from which the institute could have been taken up during its hypothetical journey from the Mediterranean to Baltic sea. This way the Nomos Rhodion Nautikos, Roles of Oleron, Vonnesse van Damme, and Visby's Waterrecht are presented. The municipal laws of Lübeck and Hamburg are then analyzed. The main goal, however, is not to present a detailed analysis, but to somehow briefly show the basics of both general average and of the German Hanse to the Czech reader.
\end{abstract}

\section{Keywords:}

The German Hanse; general average; Lübeck municipal law; Hamburg municipal law; Rôles d'Oléron; maritime law

\section{Klíčová slova:}

Německá hanza; společná havárie; lübecké městské právo; hamburské městské právo; Roles de Oleron; námořní právo

DOI: $10.14712 / 2464689 X .2018 .47$ 
Jen velice málo právních institutů vykazuje v průběhu věků takovou stabilitu jako tzv. společná havárie. Tato práce si ji klade za úkol jednak v krátkosti představit, jednak pojednat o její existenci v právních řádech doléhajících na osoby námořníků a obchodníků podnikajících v regionu tzv. Německé hanzy. Pro potřeby této práce postačí v tomto směru představa o Hanze jako obchodním společenství, jehož vliv sahal od pobřeží Flander na západě, po Novgorodské knížectví na východě, s centry v říšských přístavech Hamburku a Lübecku. ${ }^{1}$

Jelikož se jednalo především o společnost založenou na obchodních zájmech, nutně existovala potřeba upravit odpovědnostní vztahy týkající se jak obchodu samotného, tak přepravy obchodovaných komodit. A jedním z institutů tyto vztahy definující byla i společná havárie, která svou podstatou vedla k rozložení břemene škody na co největší počet osob, čímž snižovala individuální zatížení a de facto tak podstatou předcházela pojištění - ovšem jen a pouze v určitých, relativně striktně vymezených, př́ípadech.

Ačkoliv existuje řada publikací o jejím současném životě, o životě středověkém jich pojednává pramálo, ${ }^{2}$ což platí o českojazyčném prostř̌edí dvojnásob. ${ }^{3}$ Právě proto vzniká potřeba nejprve čtenáře do problematiky obecně - a stručně - uvést.

\section{Společná havárie}

Společnou havárií se rozumí specifický institut vzniku povinnosti náhrady škody. Pravidlem v námořní přepravě vždy bylo, že obecnou odpovědnost za náklad nese provozovatel plavidla, resp. kapitán, přičemž se z podstaty vzniku škody touto odpovědností kryla jak škoda vzniklá úmyslným zaviněním, tak nedbalostí - a to jak jeho (v osobě kapitána), tak posádky. ${ }^{4} \mathrm{Na}$ druhou stranu možnost výskytu situace, kdy dojde ke škodě na majetku, aniž by takový předpoklad z jeho strany existoval, nelze z podstaty námořní přepravy nikdy zcela vyloučit. Český cestovatel Rudolf Krautschneider trefně poznamenává: „Plánovat můžete, ale stejně máte na moři šéfa, který se jmenuje Neptun nebo Poseidon, a ten to

1 O Hanze (mluvíme-li o německé, pak používám označení s velkým H, jelikož existovalo více takovýchto spolků obchodních měst, největšího historického významu však nakonec dosáhl právě z dnešního pohledu německý) viz DOLLINGER, P. The German Hansa. Stanford CA: Stanford University Press, 1970, resp. DOLLINGER, P. Die Hanse. 5. Aufl. Stuttgart: Kröner, 1998, dále SELZER, S. Die mittelalterliche Hanse. Darmstadt: Wissenschaftliche Buchgesellschaft, 2010.

2 Např. HARVEY M. - HUDSON G. N. The York-Antwerp Rules: The Principles and Practice of General Average Adjustment. $3^{\text {rd }}$ edition. New York: Routledge, 2010, dále CORNAH, R. A Guide to General Average. In: Charles Taylor plc [online]. 8. 8. 2013 [cit. 21. 5. 2017]. Dostupné na: https://www.ctplc .com/media/72233/A-Guide-to-General-Average.pdf. Co do středověké úpravy viz FRANKOT, E. Medieval Maritime Law and its Practice in the Towns of Northern Europe: a Comparison by the example of Shipwreck, Jettison and Ship Collision. Aberdeen: 2004. Disertační práce (Ph.D.). University of Aberdeen; dále monografie LANDWEHR, G. Die Haverei in den mittelalterlichen deutschen Seerechtsquellen: vorgelegt in d. Sitzung vom 28. Juni 1985. Hamburg: Joachim-Jungius-Ges. d. Wiss, 1985.

3 Zmiňuje se o ní např. učebnice NOVÁK, R. - KOLÁŘ, P. Námoŕní nákladní přeprava. Praha: C. H. Beck, 2015, př́ípadně monografie ŠUBERT, M. Společná havárie v námořni a ve vnitrozemské vodni dopravě. Praha: ICC Česká republika, 2007. Historickou římskoprávní úpravou se zabýval dr. Dostalík ve svém článku DOSTALÍK, P. - POLÁČEK, B. Lex Rhodia de iactu a společná havárie. Právněhistorické studie, 2017 , roč. 47 , č. 1 , s. 5-24.

4 V tomto směru hovoří např́íklad článek 5 odst. 1 Sdělení Ministerstva zahraničních věcí č. 193/1996 Sb., Úmluva Organizace spojených národů o námořní přepravě zboží, 1978, srov. MUKHERJEE, P. K. Essentials of General Average: A Synoptic Overview of an Ancient Maritime Law. World Maritime University Journal of Maritime Affairs, 2007, Vol. 6, No. 1, s. 21-36. 
rozhodne za vás. “5 Bouřím a mořským proudům neporučíme, o tom už jsme se zvládli přesvědčit, a proto taková vis maior je, byla a nejspíš i vždy bude muset být uznávána právem coby liberační důvod.

Mezi takto nastíněnými dvěma póly v oblasti odpovědnostních vztahů se nicméně skrývá ještě jedna možnost: Existuje situace, kdy hrozí nebezpečí, že dojde ke škodě na věci svěřené k dopravě způsobené vyšší mocí, avšak takovou škodu lze minimalizovat a/nebo dokonce odvrátit tím, že dojde k záměrnému zpơsobení škody nižší. Pro lepší představitelnost se jako základní skutková podstata uvádí nutnost snížení hmotnosti plavidla (zpravidla v případě najetí na mělčinu - dnes např. case $M / V M S C$ Sabrina), ${ }^{6}$ resp. vyhození části nákladu do moře (či dnes častěji přeložení na plavidlo jiné). ${ }^{7}$ Spojuje se zde jednak právní skutečnost involuntární - tedy skutečnost hrozby vyšší mocí - s povinností odborné péče ze strany kapitána (resp. provozovatele), a tedy s jeho voluntárním právním jednáním vedoucím ke vzniku škody. Stručně shrnuto: není zde vyšší moci, která by škodu způsobila, nelze jí tedy argumentovat co do liberace, a co hůr̆, jednání kapitána, který dá pokyn k hození jemu svěřené přepravované věci přes palubu, lze kvalifikovat jako úmyslné zavinění škody na této věci - přesto se zohlední pohnutka, ze které takový čin pramení, a provozovatel tak nehradí škodu celou a sám, ale vznikne solidární povinnost náhrady škody mezi kapitánem (provozovatelem) a všemi vlastníky přepravovaného zboží, na kterém škoda způsobena nebyla. ${ }^{8}$

I dnes je společná havárie součástí např́klad Hamburských pravidel o konosamentech, ${ }^{9}$ je jí vyhrazena mezinárodně soukromoprávní kodifikace známá jako Yorsko-antverpská pravidla, ${ }^{10}$ a pamatuje na ni i český zákon $61 / 2000$ Sb. o námořní plavbě. ${ }^{11}$

Nejrozšířenější moderní úprava společné havárie vychází z jejího pojetí formulovaného výše zmiňovanými yorsko-antverpskými pravidly, vytvořenými v druhé polovině 19. století. ${ }^{12}$ Ačkoliv ze své povahy tato kodifikace není a priori závazná, je standardem uvádět na ni odkaz v konosamentu. Do smluvního vztahu si tak úprava najde pomyslné dveře právě touto cestou. Vzhledem k její uživatelnosti je samozřejmé, že se nenachází ve stavu konce devatenáctého století, ba naopak, téměř každoročně dochází k její aktualizaci.

5 Moře je nejbezpečnějším místem na světě, tvrdí mořeplavec Rudolf Krautschneider. Český rozhlas [online]. 4. 5. 2017 [cit. 21. 5. 2017]. Dostupné na: http://www.rozhlas.cz/leonardo/magazinleonardo/_zprava/more -je-nejbezpecnejsim-mistem-na-svete-tvrdi-moreplavec-rudolf-krautschneider--1723146.

6 A Story of General Average and the M/V MSC Sabrina. Trade Risk Guaranty Blog [online]. [cit. 21. 5. 2017]. Dostupné na: https://traderiskguaranty.com/trgpeak/general-average-msc-sabrina-story/.

7 CORNAH, R., c. d., s. 7.

8 General Average Definition. In: Duhaime’s Law Dictionary [online]. 6. 10. 2018 [cit. 6. 10. 2018]. Dostupné na: http://www.duhaime.org/LegalDictionary/G/GeneralAverage.aspx, CORNAH, R., c. d., s. 6, SÁNCHEZ-MORENO ELLART, C. Law of the sea, Rhodian. In: Academia.edu [online]. 6. 10. 2018 [cit. 6. 10. 2018]. Dostupné na: https://www.academia.edu/4401700/Lex_Rhodia_Encyclopedia_of_Ancient_History.

9 Viz již zmiňované Sdělení č. 193/1996 Ministerstva zahraničních věcí.

10 Aktuální znění viz York Antwerp Rules 2016. Comité Maritime International [online]. 5. 6. 2018 [cit. 5. 10. 2018]. Dostupné na: http://www.comitemaritime.org/Uploads/Work\%20Product/York-Antwerp \%20Rules\%202016\%20(Final).pdf.

11 § 69-72 zákona č. 61/2000 Sb., o námořní plavbě.

12 HARVEY - HUDSON, c. d., s. 10-11. 


\section{Společná havárie v ř́mském právu}

Samotný institut společné havárie však není žádnou novinkou devatenáctého století. Jeho historie spadá daleko do minulosti - první doložený výskyt se objevuje v Digestech (ze šestého století, kompilujících však díla velkých právníků především století druhého až třetího), kde konkrétně ve 14. knize, druhém titulu hovoří Paulus o rhodském zákonu o vyhozeném (Lex rhodia de iactu): „Pokud je zboží vyhozeno pro všechny, pak se mají všichni také př́spěvkem podílet na náhradě.“13

Panuje všeobecná shoda, že Paulův fragment zachycuje právní obyčej mnohem staršího data než rímská úprava vrcholného období. Některé hlasy dokonce hovoří i o původu v dobách předřímských. ${ }^{14}$ Navíc se nevyskytuje jen v Digestech, ale také v tzv. Paulových sentencích, ${ }^{15}$ konkrétně v knize druhé, fragmentu sedmém - ad legem Rhodiam - ze století třetího. ${ }^{16}$ Jednalo se tedy nejen o úpravu velice starou, ale i rozšířenou - a tak zřejmě i hojně užívanou.

Další výskyt je zaznamenán v Rhódském námořním zákoně - Nomos Rhodion Nautikós, právní památky byzantské provenience, vzniklé někdy mezi lety $600-800 .{ }^{17}$ Právě v něm začíná to, co vnímám jako adaptaci institutu dobovým podmínkám, a co je naopak často interpretováno jako proměna institutu ve své nejhlubší podstatě: dochází k prvním významnějším definicím druhotných odpovědnostních povinností jednotlivých stran dopravního kontraktu, a tak je stanovena např́iklad odpovědnost kapitána za přetížení lodi (vyhozené zboží nepodléhá společné havárii) nebo odpovědnost kupce za to, že naloží zboží na jiném místě, než avizoval při uzavření smlouvy. Také se poprvé objevuje aplikovatelnost institutu na škodu způsobenou piráty. ${ }^{18}$

\section{Pravidla z Oléronu (Rôles d'Oléron)}

Opust'me však nyní vody Středozemního moře a zamiřme do moře Severního a Baltského. Nejdřive se ale přeci jen musíme zastavit ještě někde jinde - na jednom $z$ ostrovů v Biskajském zálivu, nacházejícím se nedaleko břehů dnešní Francie - na Oléronu. Právě odtud pochází středověká kodifikace námořního práva, která výrazně ovlivnila všechny vzniklé a užívané na sever od padesáté rovnoběžky.

Tzv. Pravidla z Oléronu nebo Zákony z Oléronu mají poměrně nejistý původ, podobně jako Rhódský námořní zákon. Autoři se dnes již shodnou, že jejich vznik lze datovat

13 BLAHO, P. - SKŘEJPEK, M. a kol. Digesta seu Pandectae/Digesta neboli Pandekty: Fragmenta selecta/ Vybrané části. Karolinum: Praha, 2015, s. 625.

14 Viz např. FERRÁNDIZ, E. M. Will the Circle Be Unbroken? Continuity and Change of the Lex Rhodia's Jettison Principles in Roman and Medieval Mediterranean Rulings. Al-Masāq: Journal of the Medieval Mediterranean. 2017, Vol. 29, No. 1, s. 44, hovoří se zde o období před punskými válkami a pod poznámkou pod čarou č. 14 o translaci ustanovení do římského právního řádu již v období sestavení Zákona dvanácti desek, údajně ovlivněného řeckým právem (zdá se pravděpodobné, že existoval-li římsko-řecký vztah takovéto úrovně, pak skutečně mohlo dojít k přenesení právní úpravy i z Rhodu do Říma).

15 Sentence nemají s právníkem Paulem mimo jména téměř nic společného. Jejich autorem je některý z postklasických komentátorů, a jen nedorozuměním se dílo za Paulovo dlouho považovalo, a to i osobou takové autority, jakou byl svého času římský císař Konstantin. Viz např. KINCL, J. - URFUS, V. - SKŘEJPEK, M. Rímské právo. Praha: C. H. Beck, 1995, s. 39.

16 FERRANDIZ, c. d., s. 41.

17 ASHBURNER, W. Nomos Rodiōn nautikos: The Rhodian Sea-Law. Oxford: Clarendon press, 1909, s. LXXVI, srov. FERRANDIZ, c. d., s. 42.

18 ASHBURNER, $c$. d., s. CCLVII-CCLVIII, FERRANDIZ, c. d., s. 50. 
do dvanáctého století, ovšem kdo je autorem a kdo je autoritou, která je posvětila, v tom jasno není. Existují dvě nejpravděpodobnější teorie.

Podle první je kodifikace projevem vůle anglického krále. Zájem anglické koruny na takové kodifikaci se jeví evidentním - přeci jen Gaskoňsko nejen, že jí často stranilo díky čilým obchodním stykům, ale také jí díky sňatku Eleonory Akvitánské s Jindřichem Plantagenetem př́mo podléhalo. Problém přichází v momentě, kdy listinu srovnáme $\mathrm{s}$ jinými, obdobnými listinami téže doby. ${ }^{19}$ Král Richard I. Lví srdce, který má být jejím „dárcem“, je v kodifikaci sotva zmíněn, a to i zprostředkovaně, což by se vzhledem ke konstrukci soudobých dokumentů jevilo jako čirá kuriozita. ${ }^{20}$

Pravděpodobnější se tak zdá teorie druhá, podle které za prosazením jednotných pravidel stály více či méně trvalé svazy a spolky přístavních měst, které tímto způsobem mohly upevňovat své postavení vưči koruně, a to ne vždy nutně pouze anglické. ${ }^{21}$ Případné posvěcení ze strany alespoň některé z korun zainteresovaných v námořním obchodu by pak dodalo potřebný punc autority a zjednodušilo vymáhání zaznamenaných pravidel. Tímto podobným způsobem vzniklo de facto i samo hanzovní společenství, 22 což také přidává body takové alternativě na úkor teorie o „vnucení pravidel shora“.

At' už je původ oléronské kodifikace jakýkoliv, jedná se o první čistě středověkou právní památku s přesahem do hanzovního regionu. Kdokoliv ji sestavil, navíc pamatoval ve článku VIII, a částečně pak ve článku XVI, na společnou havárii. ${ }^{23}$ Článek VIII uvádí: „Jestliže se stane, že je naložena lod' k plavbě z Bordeaux do Caen, nebo kamkoliv jinam, a moře se rozbouří do takové míry, že není možno se zachránit aniž by byla část nákladu hozena přes palubu kvůli odlehčení lodi, a zachovat díky tomu zbytek nákladu, stejně jako lod' samotnou, pak by měl kapitán říci: Pánové, musíme shodit část nákladu přes palubu; a pokud není žádných kupců, co by mu odpověděli, či ti, kdož u něj stojí, schvalují takové jednání mlčením, smí vykonat, co považuje za správné; a jestliže mu kupci zakážou takový čin, a to i vzhledem k části nákladu, a on přesto pokračuje, aby tím vyhověl obecnému dobru a bezpečnosti, pak musí on a třetina jeho námořníků po př́jezdu

19 HEEBØLl-HOLM, T. Ports, Piracy, and Maritime War. Leiden - Boston: Brill, 2013, s. 130-131, srov. WARD, R. The World of the Medieval Shipmaster: Law, Business and the Sea, 1350-1450. Rochester: Boydell Press, 2009, s. 20, srov. MOLLAT, M. D. Europa und das Meer. München: Beck, 1993, s. 129, který razí starší teorii o oléronských pravidlech coby výsadě udělené oléronským Eleonorou Akvitánskou. Tato teorie nemá však hlubší reálný základ.

20 Vzpomeňme libovolné privilegium - vždy bývá uděleno coby dar vyšší moci ztělesněné dárcem. Jen jeden př́klad za všechny: Ve velkém privilegiu Václava I. pro město Brno (vydaného asi padesát let po vzniku pravidel z Oléronu) se dočteme formulace jako „poskytujeme z naší královské milosti“ (...) „Stanovíme tedy, že zabije-li někoho měšt’an (...) Nařídili jsme též, aby kdokoli by se účastnil bitky nebo rvačky (...) My jsme ze zvláštní milosti rozhodli vyhovět prosbám našich milých brněnských měštanů... " Privilegium českého krále Václava I. z ledna roku 1243 pro město Brno. Brno: Iura Originalia Civitatis Brunensis, 1993.

21 HEEBØLL-HOLM, c. d., s. 131.

22 Srov. např. JAHNKE, C. The City of Lübeck and the Internationality of Early Hanseatic Trade. In: WUBS-MROZEWICZ, J. - JENKS, S. (eds.). The Hanse in Medieval and Early Modern Europe. Leiden: Brill, 2012, s. 37-58.

23 Použit je anglický překlad textu z roku 1266, viz The Rules of Oleron (circa 1266). In: Admiraltylawguide. com [online]. 18. 3. 2002 [cit. 21. 5. 2017]. Dostupné na: http://www.admiraltylawguide.com/documents/ oleron.html, dále jen Roles of Oleron; částečné překlady ustanovení včetně fragmentů původního textu lze nalézt v poznámce pod čarou č. 197 ve FRANKNOT, E. Medieval Maritime Law, s. 43, o existenci regulace hovoří též FRANKNOT, E., Medieval Maritime Law, s. 38. 
do prŕístavu vykládky přísahat na evangelia, že tak činil jen a pouze pro zachování lodi samotné a nákladu, který na ní zůstal. A víno, či jiné zboží, které bylo shozeno přes palubu, bude oceněno podle hodnoty ostatního zboží, které dorazí v pořádku. A až takové zboží bude prodáno, pak bude hodnota rozdělena librou za libru mezi obchodníky. Kapitán smí odečíst škodu, která byla způsobena jeho plavidlu, anebo započíst přepravné za vyhozené zboží, podle svého výběru. Jestliže se však činy kapitána a jeho posádky nebudou zdát jako činy schopných námořníků, pak nemá právo na nic. Námořníci pak smí mít jeden soudek zadarmo, a další rozdělený podle hodu kostkami, a v tomto př́ípadě mohou kupci vyžadovat na kapitánovi př́sahu. “24

Toto ustanovení nádherně ilustruje prostředí, ve kterém oléronská kodifikace vznikla: Obchod mezi Akvitánií, Anglií, Flandry, a v návaznosti na ně pak i hanzovním společenstvím ovládal obchod s vínem. Kapitán získával přepravné velice často nejen jako př́mý plat za pronájem plavidla (musel by pak být vlastníkem), či jako odměnu za smlouvu o dílo - přepravu věci - jako v římském právu, ${ }^{25}$ ale sám mohl naopak vlastnit podíl na zboží, anebo - což nám oléronská pravidla říkají zcela bezděčně - byl placen podílem na úspěšně dovezeném zboží. Ratio této úvahy vychází z faktu, že bylo-li možné náhradu škody takovouto formou zaplatit, nejednalo se o transakční formu neobvyklou. Běžně se s ní mohlo operovat i v rámci obchodního styku mezi provozovateli lodní přepravy a uživateli takové služby - tedy kapitány (př́ípadně provozovatele zastupující) a kupci. ${ }^{26}$

V oléronských pravidlech se silně projevuje typický prvek středověkého předpisu: přísná kazuistika. Na druhou stranu je to kazuistika směřující k použití analogického výkladu hypotézy právní normy, nejedná se o kazuistiku ve smyslu jeho restrikce: vztahuje-li se z textu pravidlo na plavbu mezi Bordeaux a Caen nebo jakýmkoliv jiným městem, neznamená to, že dovolala-li se strana oléronských pravidel v Bayonne, kam doplula z Winchelsea, automaticky to znamenalo nemožnost takové žaloby. Na druhou stranu takováto kazuistická pravidla zcela jistě zachycují určitou obecně obvyklou praxi, nelze tedy ignorovat

24 „If a vessel be laden to sail from Bordeaux to Caen, or any other place, and it happens that a storm overtakes her at sea, so violent, that she cannot escape without casting some of the cargo overboard for lightening the vessel, and preserving the rest of the lading, as well as the vessel itself then the master ought to say, Gentlemen, We must throw part of the goods overboard; and, if there are no merchants to answer him, or if those that are there approve of what he says by their silence, then the master may do as he thinks fit; and if the merchants are not pleased with his throwing over any part of the merchandise, and forbid him, yet the master ought not to forbear casting out so many of the goods as he shall see to be for the common good and safety; he and the third part of his mariners making oath on the Holy Evangelists, when they arrive at their port of discharge, that he did it only for the preservation of the vessel, and the rest of the lading that remains yet in her. And the wines, or other goods, that were cast overboard, ought to be valued or prized according to the just value of the other goods that arrive in safety. And when these shall be sold, the price or value thereof ought to be divided livre a livre among the merchants. The master may compute the damage his vessel has sustained, or reckon the freight of the goods thrown overboard at his own choice. If the master does not make it appear that he and his men did the part of able seamen, then neither he nor they shall have any thing. The mariners also ought to have one tun free, and another divided by cast of the dice, according as it shall happen, and the merchants in this case may lawfully put the master to his oath." Viz Roles of Oleron.

25 KINCL - URFUS - SKŘEJPEK, c. d., s. 255.

26 V tomto směru srov. DOLLINGER, The German Hansa, s. 152-153, týkající se hanzovního obchodu, kde se popisuje obdobná praktika. 
narativní hodnotu textu, kromě jeho hodnoty právněhistorické - a tedy legistické. ${ }^{27}$ Tato úvaha je důležitá proto, že představuje jeden ze základních rozdílů náhledu na právní texty očima historika - osoby, pro kterou je primární př́běh skrytý pod rouškou právní regulace; a specificky právního historika - tedy osobu, pro kterou je důležitá sama právní regulace a její interpretace.

\section{Obyčeje z Damme (Vonesse van Damme) a Ordonance (Ordinancie)}

Díky čilému obchodu se šíril podél pobřeží i způsob jeho regulace - a tak se na konci třináctého století (nejpozději na počátku století čtrnáctého) objevuje v bruggském př́istavu Damme právní kniha či spíše obecně uznávaná sbírka pravidel označovaná jako Obyčeje z Damme. Nejde o sbírku originální - naopak: jedná se o překlad oléronského textu do vlámštiny. Už v základu tak logicky musel obsahovat - a obsahoval - ustanovení týkající se společné havárie. ${ }^{28}$

Na Obyčeje navazuje soupis tzv. Ordonancí. Ty jsou podle některých samostatnou sbírkou, ${ }^{29}$ podle jiných pak pouze doplněním Obyčejů ${ }^{30}-\mathrm{v}$ tomto směru je vskutku velký prostor pro argumentaci i výzkum, jelikož relevantní argumenty s dnešním stavem vědění lze nalézt pro obě strany. ${ }^{31}$

Co do podstaty sbírky, jde o námořní obyčeje sesbírané v druhé polovině čtrnáctého století ve Flandrech, v okolí Zuiderzee. Neobsahují přímo oléronská pravidla, ale několik článků se zde evidentně ocitlo př́mým převzetím z Obyčejů. Po jistou dobu pak obě právní památky existovaly paralelně vedle sebe, načež se začaly šírit ve společných manuskriptech, a to ve velkém množství. ${ }^{32}$

Existuje teorie, podle které tak mělo docházet ke snaze o unifikaci námořních pravidel v západoevropském prostoru. ${ }^{33} \mathrm{Nad}$ ní však visí Damoklův meč otázky, z čí iniciativy mohlo něco takového vyjít. Největší zájem by na tom bezpochyby měli samotní kupci, jelikož jednotnost právní úpravy zvyšuje právní jistotu co do právního povědomí, a tím pádem usnadňuje vymáhání nároků, a tedy i samotné provozování kupecké živnosti, ovšem důkazy k takové teorii chybí. Stejně jako jakákoliv stopa po autorizované snaze „shora“. Bez ohledu na to se Ordonance s Obyčeji stanou základními kameny pro nejznámější kodifikaci obyčejového námořního práva severní Evropy - tzv. Vodního práva (Waterrecht).

\section{Městská práva v oblasti}

Ještě předtím, než však bude představeno, je třeba udělat odbočku k městským právům a jejich vztahu k právu námořnímu. V této oblasti právních vztahů se uplatňoval zvláštní režim, vyplývající z logické snahy jednotlivých měst o co největší autonomii: pokud

27 K tomuto vede definice obsahu práva a právního vědomí společnosti podle KNAPP, V. Teorie práva. Praha: Beckovy právnické učebnice, 1995, s. 75-76, resp. Tamtéž, s. 82-85.

28 FRANKOT, E. Maritime Law and Practice in Late Medieval Aberdeen. The Scottish Historical Review. Edinburgh: Edinburgh University Press, 2010, Vol. 89, No. 228, s. 136-152, s. 137; FRANKOT, Der Ehrbaren Hanse-Städte See-Recht, s. 112, Tamtéž s. 116, FRANKOT, Medieval Maritime Law, s. 21.

29 Např. FRANKOT, Der Ehrbaren Hanse-Städte See-Recht, s. 116.

30 Např. DOLLINGER, The German Hansa, s. 148.

31 Viz FRANKOT, Der Ehrbaren Hanse-Städte See-Recht, s. 116.

32 Tamtéž.

33 Tamtéž. 
si totiž určitou oblast právních vztahů upravilo město svým vlastním právem, at' už šlo o „Willkür“, hlavně gdańské městské statuty, či lübecké a hamburské právo ve smyslu městských právních knih, pak se kodifikace obyčejového námořního práva použila jen podpůrně: bud' pro př́ípady, na které nedopadala, nebo jako určité referenční kritérium. Navíc platil princip personality práva: byl-li tak např́klad kapitán měšt’anem hanzovního města Lübecku, podléhal regulacím lübeckého práva. ${ }^{34}$

Mezi městským právem a právem námořním panoval ještě jeden významný rozdíl, důležitý pro chápání středověkého právního myšlení. Zatímco kvazi-mezinárodní právo námořní obsahovalo zpravidla regule vztahující se z dnešního hlediska na soukromoprávní jednání, tedy ta, za něž hrozila sankce vydání bezdůvodného obohacení nebo náhrady škody, ${ }^{35}$ práva městská směřovala i k sankcím veřejnoprávním: pokutám či kriminálním postihům. Nutno podotknout, že tyto pokuty směřovaly poté do městské pokladny, nikoliv k rukám strany sporu. ${ }^{36}$

Problémem při zkoumání středověkých právních úprav je omezení vyplývající z tristního nedostatku dochovaného materiálu - u lübeckého námořního práva tak lze např. dohledat nejstarší edice pouze k roku 1227. Následně, díky praxi „darování“ právního řádu již existujícího města nově právně založenému městu, se objevuje lübecké právo v roce 1257 v Talinnu (Revalu) a 1263 v Gdańsku.

Pokud mluvíme o námořním právu, vždy se jedná o součást obecného městského práva, zkoumaného však pro jeho účel odděleně. Platí tak pro něj všechny atributy s ním spojené: vychází bud' z právních obyčejů, nebo se jedná o statuty vydávané městskou radou, a edice jsou zpravidla právními knihami, sestavovanými soukromými osobami, pracujícími bud' př́mo v městské radě, nebo alespoň s jejím požehnáním. ${ }^{37}$

Lübecké námořní právo z roku 1227 tvoří jedna jediná regulace - pravidlo upravujícího provoz veslic - pramic. ${ }^{38}$ Společná havárie se tak poprvé objevuje až v manuskriptu lübeckého práva pro Talinn (Reval) v jeho článku 90, resp. v článcích 94 a 95 práva pro Gdańsk z roku 1263. Ač nebyly zřejmě původně jeho součástí, nejpozdější výskyt lze dopátrat mezi roky $1263-1275 .{ }^{39}$ Od té doby se tato ustanovení objevují v dalších edicích, ${ }^{40}$ a to i v poslední, definitivně samostatné edici námořního práva, obsahující všechny jeho předchozí regule z práva městského, z roku 1299, kdy ji sestaví Albrecht z Bardeviku. ${ }^{41}$

Výše zmíněný nejstarší článek 90 talinnského (revalského) lübeckého práva z roku 1263, nazvaný O věcech hozených z lodi (De bonis eiectis de naui) říká:

FRANKOT, Medieval Maritime Law, s. 24.

A to i prostřednictvím fixní částky - pokuty, placené smluvní straně. Nejednalo v žádném př́ípadě o smluvní pokutu - pramenila vždy z právního obyčeje, resp. kodexu.

FRANKOT, Medieval Maritime Law, s. 24.

Konkrétně k lübeckému právu viz např. PÄSLER, R. G. Lübisches Recht. In: Online-Lexikon zur Kultur und Geschichte der Deutschen im östlichen Europa [online]. 6. 10. 2018 [cit. 5. 10. 2018]. Dostupné na: http://ome-lexikon.uni-oldenburg.de/begriffe/luebisches-recht/; dále EBEL, W. Lübisches Recht. Lübeck: Max Schmidt-Römhild, 1971, s. 168 a násl., obecně pak heslo Stadtrecht in: BAUTIER, R.-H. - AUTY, R. - ANGERMANN, N. (eds.). Lexikon des Mittelalters. München: Deutscher Taschenbuch Verlag, 2003, SV. 8, sl. 24-26.

FRANKOT, Der Ehrbaren Hanse-Städte See-Recht, s. 110, FRANKOT, Medieval Maritime Law, s. 71. FRANKOT, Medieval Maritime Law, s. 72.

FRANKOT, Medieval Maritime Law, s. 25 a násl., Tamtéž, s. 72.

FRANKOT, Medieval Maritime Law, s. 75. 
„Jakékoliv zboží, které je z důvodu nevyhnutelného rizika nehody vyhozeno do moře, zaplatí všichni, kteří na lodi měli své zboží. A lod' stejně jako zboží bude oceněno tak říkajíc na marktál, podle marky stříbra. A každý zaplatí hodnotu podle hodnoty zboží v přístavu, kam zboží míŕilo.“42

Dolnoněmeckou verzi lze přeložit jako: „Zboží, které je na moři kvůli neodvratnému nebezpečí vyhozeno přes palubu, zaplatí všichni, kteří na lodi zboží měli, a to stejným dílem. A lod' stejně jako zboží těch, kteří jej měli na palubě, bude oceněno na marktál. A také platí, že cena zboží bude vyjádřena podle př́istavu, kam bylo zamýšleno [jej přepravit].“43

Pro porovnání uved'me textaci dalšího, neméně významného městského práva oblasti - hamburského. Jeho nejstarší dochovaná kopie pochází z roku 1279 ze Stade, a je psaná dolnoněmecky. ${ }^{44}$ Hamburk měl přitom zcela jistě latinsky psané právo minimálně od roku $1225,{ }^{45}$ a některé zdroje hovoří o roku 1188 . Jelikož tehdy dochází k založení města v právním slova smyslu, zůstává jedinou spornou otázkou použitý jazyk. ${ }^{46}$ Nicméně informace, které o této hypotetické latinské verzi máme, jsou velmi kusé. Údajně obsahovalo některá pravidla podobná lübeckým, silně ovlivňující jeho další vývoj. ${ }^{47}$ Taková informace nám in concreto dává možnost jen konstatovat, že vzhledem k minimálnímu množství relevantních lübeckých regulí nejspíše i Hamburk v té době nedisponoval příliš rozvinutým námořním právem - a to minimálně do roku 1227, kdy došlo k zaznamenání lübeckého článku o pramicích. ${ }^{48}$

U Hamburku nicméně narážíme na určitou zvláštnost. Ačkoliv se pravidla námořního práva přímo v městském právu vyskytují, postupně dochází k jejich vyčlenění do samostatného odvětví, nazývaného sciphelinge, která začíná žít vlastním právním životem - už v roce 1259 se o ní zmiňuje dopis Hamburku zaslaný Lübecku, ${ }^{49}$ a v roce 1270 , kdy notár Jordan z Boizenburku sestavuje kodifikaci městského práva, je mu věnován vlastní oddíl. Někdy mezi lety 1301-1306 dochází dokonce k jeho samostatné kodifikaci, v jejímž úvodu městská rada obě práva - městské a námořní - důsledně odlišuje. ${ }^{50}$ Jeho vývoj je završen

42 Překlad z latinské verze: Quecumque bona ex infortunio periculo imminente de naui eiecentur in mari. Omnes ea soluere tenentur qui bona habent in naui. Et nauis similiter secundum estimationem bonorum de marca argenti quod uulgo marctale dicimus. Et secundum, quod quelibet bona eiecta soluere, soluere poterant in terra vel portu quem cum eisdem bonis tendebant. VON BUNGE, A. G. Die Quellen des Revaler Stadtrechts II. Band. Dorpat: Franz Kluge Verlag, 1846, s. 35.

43 „Dat gudes an der see van ungeludes wegene wert ut gheworfen alle de dar gut in deme schepe hebben de sint is plichtich to betalende. Unde dat schip des gelifen na guder lude segende na marktale. Unde also dure also dat gud gelden mochte in deme lande dar ze henne dachten."VON BUNGE, c. d., s. 35.

44 FRANKOT, Der Ehrbaren Hanse-Städte See-Recht, s. 111.

45 Tamtéž.

46 PISCHKE, L. Hamburger Stadtrecht von 1188. In: Hamburg im Spätmittelalter [online]. 20. 12. 2016 [cit. 21. 5. 2017]. Dostupné na: http://www.spaetmittelalter.uni-hamburg.de/spaetmittelalter/Lehre/Ergebnisse /Hamburg/glossar.html.

47 Koneckonců je pravda, že Lübeck v té době (cca dvacet let po jeho založení) zažíval prudkou ekonomickou a mocenskou expanzi. Viz JAHNKE, c. d., s. 46-47.

48 Což nevylučuje existenci pravidla dříve - přeci jen se jednalo o právní obyčej.

49 Zřejmě se jedná o korespondenci mezi jednotlivými městskými radami. Viz FRANKOT, Medieval Maritime Law, s. 25-26.

50 FRANKOT, Medieval Maritime Law, s. 25-26, srov. LAPPENBERG, J. M. Die ältesten Stadt-Schiff-und Landrechte Hamburgs. Hamburg: Johan A. Meissner, 1845, s. CXXXVII a násl. 
kodifikací z roku 1497 provedenou odborníkem na slovo vzatým, doktorem práv a purkmistrem hamburské rady od roku 1482, Hermannem Langebekem, ${ }^{51}$ nazvanou stroze Lodní právo (Hamburg Schiffsrecht). ${ }^{52}$

Ohledně vývoje a existence institutu společné havárie je důležité zejména dílo Boizenburkovo. Jednak chronologicky navazuje na tallinnské (revalské) lübecké právo, jednak je představitelem hamburského právního okruhu, a do třetice - jde o právo samostatné, autonomní, a to místně i účelově (upravuje práva a povinnosti hamburských měšt’anů s přihlédnutím k jejich konkrétním potřebám, které mohly být obdobné jako potřeby občanů lübeckých, ale už z podstaty vzniku a vývoje obou sídel nikoliv totožné).

V Boizenburkově článku XXII, který notář systematicky zařadil mezi ustanovení týkající se jiných náhrad škody, ve větě první stojí:

„Pokud lod' při hrozbě nebezpečí odhodí (náklad), pak bude přispěno na marktál.“53

V hamburském diplomatáři se objevuje ještě latinská formulace téhož pravidla, kterou lze přeložit jako:

„Jestliže lod', aby na moři zajistila ochranu života a zdraví, odhodí získané [zboží], pak dají kapitán spolu s kupci stejně na marktál.“54

Ačkoliv Lübeck měl tendenci pravidlo upravit konkrétněji, shoduje se s Hamburkem minimálně v principu metody kompenzace škod tzv. marktálem. Marktál („na Marktal, „mark markalike“) je praxe, kdy se veškeré zboží ocení v markách a následně se hodnota způsobené škody proporcionálně rozdělí.

Jednotlivá městská práva tedy institut společné havárie obsahovala. Její hlavní prvek - solidární odpovědnost - najdeme vždy, a to, čím se liší, je jen míra definice sekundárních práv a povinností na ni navazujících. Zatímco lübecké právo jde do podrobnosti ocenění vyhozeného zboží podle cílového přístavu a stanovení hodnoty celého nákladu na marky stř́bra, hamburské právo stroze konstatuje existenci odpovědnosti, spoléhajíc na systematiku kodifikace při zodpovídání takových otázek. Oběma městským kodifikacím je navíc společný princip marktálu, což dokazuje blízkost obou úprav.

Lze si však všimnout jednoho výrazného rozdílu: Ačkoliv hamburské právo explicitně zmiňuje kapitána coby osobu povolanou do solidárního společenství odpovídajících za škodu, v lübeckém právu tomu tak není. Hovoří se pouze o osobách, které mají zboží na palubě. Zřejmě tak dochází k promítání praxe do formulace pravidla, jelikož jak bylo již výše zmíněno, často nebyl kapitán pouze dopravcem, ale zároveň i obchodníkem, a tak mu patřila část zboží na lodi. Př́ípadně byly jeho služby určitou částí svěřeného nákladu zaplaceny.

Nebo se zde projevuje silnější vliv ř́mského práva, které kapitána nechápalo jako stranu povinnou náhradě, ale spíše jako arbitra př́ípadného sporu - odtud ostatně původ jeho zadržovacího práva ke svěřeným věcem. ${ }^{55}$

\footnotetext{
51 Stejný muž stojí i za kodifikací hamburského městského práva ze stejného roku. Viz FRANKOT, Medieval Maritime Law, s. 29-30.

52 FRANKOT, Medieval Maritime Law, s. 29-30.

53 „So wor so ein scip dor noet willen goet uthwerpt, dat scip scal mede ghelden marc markelike." Viz LAPPENBERG, $c$. $d$., s. 83.

54 „Insuper quorsum navis in mari ob tuitionem vitae et bona obtinenda proicit, ibi dabitur a magistro navis cum mercatoribus marcha marcheae coequalis.“Viz LAPPENBERG, c. d., pozn. p. čarou č. 1, s. 83.

55 ASHBURNER, c. d., s. CCLV.
} 
Nabíledni je konfrontovat obě úpravy s Oléronskými pravidly. Ta definují odpovědnost kapitána odděleně od kupců, avšak z formulace se rozumí, že ručí také solidárně - jen má právo svůj díl snížit bud' o škodu způsobenou plavidlu (sníží budoucí výdaje) nebo o přepravné (sníží př́ijem). Můžeme tak vidět bližší vztah úpravy hamburské s oléronskou, což se také nabízí: díky své poloze Hamburk skutečně orientoval svůj obchod spíše na západ a západní pobřeží Norska než na východ.

\section{Visbyské námořní právo (Vodní právo - Waterrecht)}

Poslední předmětnou kodifikací je již zmiňované Vodní právo. Jedná se de facto o kompilaci lübeckého námořního práva, které do sebe v té době již absorbovalo i některé normy samostatně kodifikovaného práva hamburského, a kompletních překladů Obyčejů z Damme a Ordonancí. ${ }^{56} \mathrm{~V}$ průběhu patnáctého století se šírilo po Baltu v rukopisech, ${ }^{57}$ přičemž jej nepochybně používaly i jednotlivé městské soudy, o čemž svědčí hned několik nálezů z Gdańsku vydaných mezi lety 1425 a 1436.

V roce 1505 pak vychází tiskem pod názvem „Visbyské námořní právo“.58 Ten dodnes zamotává hlavy nejen historikům, jelikož nemá nic společného s místem vydání, a to i přestože se úvod kodifikace ke vzniku na Visby odvolává. ${ }^{59}$ Pravděpodobně tak dochází k odkazu na místo, kde byl původní rukopis dokumentu dlouho uchováván - na gotlandském Visby. Ostatně podobná situace platí i v př́padě Oléronských pravidel a Oléronu. ${ }^{60}$

Jelikož se jednalo o kompilát existujících úprav, nedošlo v kodifikaci k opuštění principu společné havárie. Ba naopak - Obyčeje, ze kterých vychází primárně, byly přímým překladem Pravidel, a z výše uvedené analýzy je zřejmé, že i lübecké a hamburské právo institut obsahovalo. Díky tak četnému a opakovanému výskytu se z něj stal jeden ze zásadních pilírů odpovědnostních vztahů v tehdejší námořní dopravě a neexistoval důvod pro jeho vypuštění z úpravy nové. Přes Vodní právo tak vstupuje na Baltu „společná havárie“ do novověku.

\section{Hanzovní recesy (Hanserezesse)}

Jedna celá skupina pramenů zůstává touto prací opomenuta. Jedná se o tzv. hanzovní recesy, tedy dokumenty vznikající jako výsledek hanzovních sněmů, obsahující jejich usnesení. ${ }^{61} \mathrm{Je}$ to vhodné $\mathrm{z}$ několika důvodů:

Zaprvé, reces samotný zavazoval pouze město jako celek (jeho civitas), nikoliv - z dnešního pohledu - fyzické osoby. Pokud by norma přeci jen obsahovala nějaké takové právo či povinnost, mohla městská rada provést tzv. osvojení či lépe promulgaci takového pravidla skrze institut tzv. Einungu. Díky němu by se pak pravidlo stalo součástí

56 WARNKE, I. Polylinguale Intertextualitat und Konstituierung von Kultursprachen. Linguistica, 1998, Jhrg. 38, Nr. 1, s. 38.

57 WARNKE, $c$. d., s. 38.

58 WARNKE, c. d., s. 38, FRANKOT, Medieval Maritime Law, s. 28.

59 „Her beghynt dat hogheste water recht“, viz FRANKOT, Medieval Maritime Law, s. 28.

60 FRANKOT, Medieval Maritime Law, s. 28.

61 Ohledně hanzovních recesů viz heslo Rezess in: Hanselexikon.de [online]. 6. 10. 2018 [cit. 6. 10 2018]. Dostupné na: http://www.hanselexikon.de. Na konci 19. století proběhla jejich rozsálá edice, dnes z větší části dostupná online. Viz Hanserecesse. In: Hansischergeschichtsverein.de [online]. 6. 10. 2018 [cit. 6. 10. 2018]. Dostupné na: https://www.hansischergeschichtsverein.de/recherche?von=0\&bis=0\&typ= $4 \&$ suche $=$. 
městského práva, pro měšt’any přímo závazného. ${ }^{62}$ Pokud by městské právo už úpravu nějakého institutu obsahovalo, Einung by byl z důvodu duplicity nežádoucí. At’ tak, či tak, výsledek z hlediska metodiky této práce by vyšel stejný - vznikla by nutnost analyzovat městské právo, nikoliv reces, k čemuž krátce došlo.

Zadruhé - osazenstvo hanzovních sněmů s povahou závaznosti recesů počítalo, a tak normy námořního práva, které se snažilo prosadit, velice málokdy směřovaly k regulaci vztahu dvou osob mezi sebou. Mnohem častější byla úprava vztahů mezi městy či ustanovení zakládající jakési obecné normy. Lze se tak např. setkat se zavedením institutu tzv. zimního klidu (Winterlage), kdy se jednalo o zákaz plavby v zimních měsících, nebo o zákaz obchodování se zbožím, u kterého hrozila důvodná obava, že pochází ze ztroskotané lodi. ${ }^{63}$

Zatřetí - vzhledem ke specifické povaze recesů mám za to, že by bylo vhodné jim věnovat mnohem větší prostor.

Dohromady tak lze konstatovat, že vydat se cestou stručné analýzy recesů bok po boku s ostatními kodifikacemi by bylo jednak zavádějící, a jednak určitým způsobem nadbytečné, jelikož cíle článku mohou být splněny i bez ní. Přesto se v nich otevírá celý neprozkoumaný svět specifické právní regulace, který by měl být podroben opětovnému výzkumu.

\section{Závěr}

Společná havárie bezpochyby zaujala své místo $\mathrm{v}$ rámci regulace námořního obchodu i takových hráčů, jakými byla hanzovní města. Zdá se, že tento předpojišt'ovací způsob minimalizace ztráty při tak nejistém podnikání, jakým je námořní obchod, mohl do Baltského moře doslova připlout $\mathrm{z}$ jihu.

Ovšem, srovnáme-li si její jednotlivé výskyty chronologicky, tento definitivní obraz se poněkud rozostřuje. Hamburské dílo notáře Boizenburka z roku 1270 je nejspíše jen o pár let mladší než Pravidla z Oléronu z roku 1266. Jakou rychlostí se vůbec středověkou Evropou dokázaly šírit právní instituty? Nemůže jít o výskyt stejného institutu na několika místech jednoduše proto, že je logické postupovat v případě rizika právě tak, jak bylo zmíněno v úvodu - minimalizovat svou ztrátu rozložením škody mezi všechny zúčastněné? A není tím pádem jeden z typických římskoprávních institutů vlastně logickým východiskem takového záměru, bez ohledu na geografické prostředí?

Pevně věřím, že se časem díky dalšímu výzkumu podaří nalézt odpovědi nejen na tyto otázky. A ačkoliv se v současnosti vede živá diskuse o nutnosti používání natolik prastarého institutu v moderní námořní dopravě, současně věřím, že se tak podaří dříve, než nás „společná havárie“ definitivně opustí. ${ }^{64}$ Což, na trochu veselejší notu, nebude tak nepravděpodobné - zatím je s námi přeci jen něco málo přes dva tisíce let.

\footnotetext{
62 FRANKOT, Der Ehrbaren Hanse-Städte See-Recht, s. 118.

63 FRANKOT, Der Ehrbaren Hanse-Städte See-Recht, s. 118.

64 MUKHERJEE, P. K. The Anachronism in Maritime Law that is General Average. World Maritime University Journal of Maritime Affairs, 2005, Vol. 4, No. 2, s. 195.
} 